\title{
Patient safety culture: perception of nursing professionals in high complexity institutions
}

\author{
Cultura de segurança do paciente: percepção de profissionais de enfermagem em instituições de alta complexidade
}

Cultura de seguridad del paciente: percepción de profesionales de enfermería en instituciones de alta complejidad

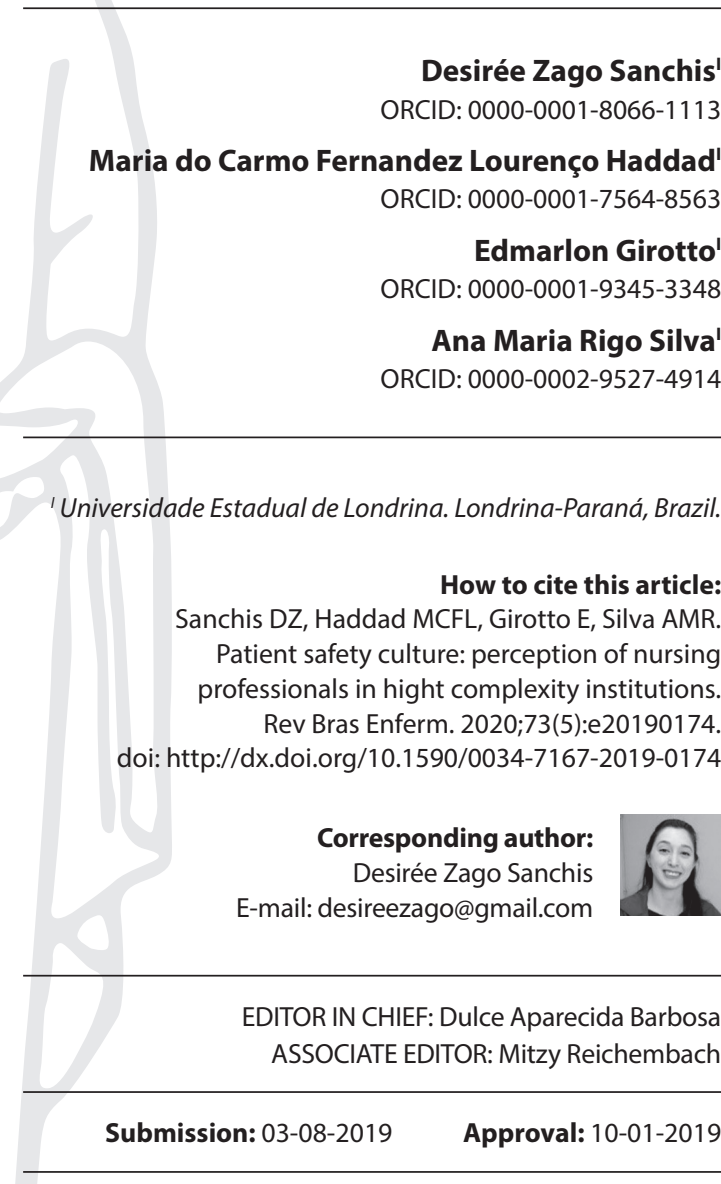

\begin{abstract}
Objectives: to analyze the perception of nursing professionals about patient safety culture in three highly complex hospital institutions. Methods: descriptive and quantitative study with professionals working in care. The Hospital Survey on Patient Safety Culture questionnaire was applied, classifying its dimensions according to the percentage of positive responses (strengthened: $\geq 75.0 \%$; potential for improvement: $<75.0 \%$ to $>50.0 \%$; weakened: $\leq 50.0 \%$ ). Results: four hundred sixty-seven professionals (79.6\%), mostly women (88.4\%), nursing technicians/assistants $(57.2 \%), 20$ to 39 years $(60.8 \%)$, less than five years in the institution (57.8\%) and exclusive bond (79.2\%) participated in the study. Safety culture was considered fragile, seven dimensions assessed as such, highlighting "Openness to communication" and "Non-punitive responses to errors" with $<30.0 \%$ positive responses. Conclusions: evidence of the need for discussion of the subject and strategies for change that promote quality and safety of care.

Descriptors: Patient Safety; Organization Culture; Nurse Practitioners; Perception; Hospitals.
\end{abstract}

\section{RESUMO}

Objetivos: analisar a percepção de profissionais de enfermagem sobre a cultura de segurança do paciente em três instituições hospitalares de alta complexidade. Métodos: estudo descritivo e quantitativo com profissionais atuantes no cuidado. Aplicou-se o questionário Hospital Survey on Patient Safety Culture, classificando-se suas dimensões segundo percentual de respostas positivas (fortalecidas: $\geq 75,0 \%$; potencial de melhoria: $<75,0 \%$ a $>50,0 \%$; enfraquecidas/ fragilizadas: $\leq 50,0 \%)$. Resultados: participaram do estudo 467 profissionais $(79,6 \%)$, a maioria mulheres $(88,4 \%)$, técnicos/auxiliares de enfermagem $(57,2 \%), 20$ a 39 anos $(60,8 \%)$, menos de cinco anos na instituição $(57,8 \%)$ e vínculo exclusivo $(79,2 \%)$. A cultura de segurança foi considerada fragilizada, e as sete dimensões foram avaliadas como tal, destacando-se"Abertura para as comunicações" $e$ "Respostas não punitivas aos erros" com $<30,0 \%$ de respostas positivas. Conclusões: evidencia-se a necessidade de discussão do assunto e estratégias de mudanças que promovam a qualidade e a segurança do cuidado.

Descritores: Segurança do Paciente; Cultura Organizacional; Profissionais de Enfermagem; Percepção; Hospitais.

\section{RESUMEN}

Objetivos: analizar la percepción de los profesionales de enfermería sobre la cultura de seguridad del paciente en tres instituciones hospitalarias de alta complejidad. Métodos: estudio descriptivo y cuantitativo con profesionales que trabajan en el cuidado. Se aplicó el cuestionario Hospital Survey on Patient Safety Culture, clasificando sus dimensiones de acuerdo con el porcentaje de respuestas positivas (fortalecido: $\geq 75.0 \%$; potencial de mejora: $<75.0 \%$ a $>50.0 \%$; debilitado: $\leq 50.0 \%$ ). Resultados: 467 profesionales $(79.6 \%)$, en su mayoría mujeres (88.4\%), técnicos/asistentes de enfermería (57.2\%), 20 a 39 años (60.8\%), menos de cinco años en el estudio, participaron en el estudio. institución (57.8\%) y bonos exclusivos (79.2\%). Cultura de seguridad fue considerada frágil, siete dimensiones fueron evaluadas como tales, destacando "Apertura a las comunicaciones" y "Respuestas no punitivas a los errores" con $<30.0 \%$ de respuestas positivas. Conclusiones: evidencia de la necesidad de discutir el tema y estrategias de cambio que promuevan la calidad y la seguridad de la atención.

Descriptores: Seguridad del Paciente; Cultura Organizacional; Enfermeras Practicantes; Percepción; Hospitales. 


\section{INTRODUCTION}

In recent years, patient safety has gained visibility in Brazil. Thus, professionals have usually been trained and the mistake, despite the punitive culture still in force, has been identified, notified and discussed more frequently. According to the report published by the Brazilian National Health Surveillance Agency (ANVISA - Agência Nacional de Vigilância Sanitária), from March to December 2018, 272,689 incidents were reported. Of the total number of reported incidents, almost two thirds caused harm to the patient and the vast majority (93.7\%) occurred in hospitals ${ }^{(1)}$. Patient safety incidents are defined as circumstances that may or may not result in harm and, when it occurs, is characterized as an adverse event. Patient safety is related to reducing the risk of unnecessary healthcare-related harm to an acceptable minimum ${ }^{(2)}$.

The Brazilian National Patient Safety Program (PNSP - Programa Nacional de Segurança do Paciente) was established in 2013 with the purpose of qualifying health care, and has as one of its implementation strategies the promotion of safety culture $^{(3)}$. In the same year, RDC 36 was established, which obliges the constitution of Patient Safety Centers (NSP - Núcleos de Segurança do Paciente) in health institutions, which should support and promote the systematic dissemination of the patient safety culture ${ }^{(4)}$.

Safety culture is considered a component of organizational culture and can be described as a set of individual or group values, attitudes, perceptions, competencies and behaviors. They will determine an organization's style and commitment to patient safety management $t^{(5)}$. Organizations with a strengthened safety culture are characterized by good communication between professionals, mutual trust and shared perceptions about the importance and effectiveness of preventive actions ${ }^{(5)}$. Organizations with a strengthened safety culture are found to have lower rates of surgical site ${ }^{(6)}$, bloodstream ${ }^{(7)}$, and morbidity infections ${ }^{(8)}$.

Safety culture is an important service management strategy that favors the implementation of safe practices and the mitigation of adverse events ${ }^{(9)}$. Therefore, safety culture assessment is required by international and national hospital accreditation organizations to identify and manage patient safety issues, to monitor changes and outcomes related to the issue ${ }^{(10)}$.

Studies that assessed the safety culture ${ }^{(11)}$, identified nationally, include hospital units ${ }^{(9-10,12-15)}$, teaching or public hospitals $s^{(16-23)}$, and less frequently hospitals with different management types ${ }^{(24)}$.

Assessing the patient safety culture is important for the extraction of information related to health institutions, making a situational diagnosis, and thus providing means for establishing improvement and strengthening actions. Thus, the present study may contribute to the assessment related to three highly complex hospitals, diverging in their particularities of care and perceptions of nursing team professionals who provide direct patient care.

\section{OBJECTIVES}

To analyze the perception of nursing professionals about patient safety culture in three highly complex hospital institutions.

\section{METODS}

\section{Ethical aspects}

The study was conducted after authorization by the board and the Research Ethics Committee responsible for the researched institutions. All participants were informed about the research objective and, after agreement, signed the Informed Consent Form.

\section{Design, period and place of study}

This is a descriptive, quantitative study with cross-sectional analysis axis. In order to ensure the quality of the study, the Scientific Writing Checklist called Strengthening the Reporting of Observational Studies in Epidemiology (STROBE) was used (25).

The research was conducted from February to April 2017, in three highly complex hospital institutions located in a large municipality in the northern state of Paraná. Hospital 1 is philanthropic, affiliated to the Brazilian Unified Health System (SUS - Sistema Único de Saúde) and has 191 beds. Supervision is carried out by four nurses, who are responsible for 141 nurses and 202 technicians/assistants. Hospital 2 is also philanthropic and affiliated to the SUS, and has 76 beds that exclusively serve pediatrics and neonatology. The nursing service is coordinated by a nurse, being responsible for 53 nurses, 60 technicians/assistants and a nurse supervising the operating room. Hospital 3 serves only private and private patients in its 65 beds. The nursing team is coordinated by a nurse, and they are responsible for 48 nurses, 83 technicians/assistants and a supervising nurse of the operating room. The general coordination of the nursing staff of the three hospitals is performed by a single nurse.

The NSP was established in 2013 and is headquartered at Hospital 1, consisting of a nurse and an administrative assistant under the responsibility of a multidisciplinary manager. Patient safety culture has been worked through the implementation of protocols that involve the patient safety goals. The NSP conducts incident analysis activities, training related to patient safety goals for nursing workers on admission and monthly for active staff. The three hospitals do not yet have a hospital accreditation certificate.

The three hospital institutions develop teaching activities in partnership with mid-level and undergraduate nursing technical courses, as well as internship for medical residency courses in 11 specialties and multidisciplinary in the areas of nursing, psychology, pharmacy, physiotherapy and nutrition.

\section{Study population}

The study population consisted of all nurses, technicians and nursing assistants belonging to the workforce of the three institutions, allocated to the medical and surgical clinics, pediatric, operating room, intensive care units (neonatal, pediatric and adult), and emergency units (adult and child). These professionals totaled 587 participants, 242 nurses, 251 nursing technicians and 94 nursing assistants.

\section{Inclusion and exclusion criteria}

All nursing professionals who worked for at least six months in the institution and performed direct patient care were included. 
Losses were considered to be professionals who were on vacation or leave/absence from work during the data collection period.

\section{Study protocol}

For data collection we used the self-completed questionnaire entitled Hospital Survey on Patient Safety Culture (HSPSC), developed by the US Agency for Healthcare Research and Quality (AHRQ) in $2004^{(11)}$. The tool makes it possible to measure the dimensions of the patient safety culture through the perception of respondents individually and by hospital unit, as well as providing the opportunity to identify areas that need improvement and assess actions implemented ${ }^{(26)}$. It was translated and validated in Brazil by Reis $(2013)^{(27)}$.

The HSPSC is subdivided into nine sections, totaling 55 questions, 44 related to security culture and 9 questions related to personal information. For the present study, two questions related to the characteristics of work in the institution were included: "Do you have other work relationships?" And "Usually, how many hours per week do you work on other work relationships," totaling 11 characterization questions. The last item of the questionnaire asks the respondent to make a recommendation on patient safety aspects, data not analyzed in this study.

The HSPSC tool is made up of 12 dimensions, and each dimension consists of three to four questions that integrate the various sections of the questionnaire. Among the dimensions, seven are related to the scope of the unit/sector organization, three are related to the hospital organization and two outcome dimensions.

The dimensions "Teamwork within hospital units", "Organizational learning", "Adequacy of professionals", "Non-punitive responses to errors", "Widespread perceptions of patient safety", "Supervisory/manager safety promotion expectations and actions", "Hospital management support for patient safety", "Teamwork within hospital units "and" Internal transfers and shifts "were answered on a Likert scale, grouped as follows: I strongly disagree/I disagree; I do not agree nor disagree; I totally agree/l agree.

The dimensions "Return of information and reporting on errors", "Openness to communication", "Frequency of adverse event reports that are reported in the various modalities" had the never-always-scale response option, grouped as follows: never/ rarely; sometimes; almost always/always.

Thus, positive answers were those that were marked "I totally/ partially agree" or "almost always/always" and for the negative questions: "I totally/partially disagree" or "never/rarely". For both formulations, the answers "I neither disagree nor agree" or "sometimes" were considered neutral.

Regarding the outcome variables, the questionnaire includes: "Patient safety degree", categorized as excellent/very good; regular; bad/very bad and the "Number of reported/notified adverse events in the last 12 months" categorized as "no reports"; "From 1 to 10 reports"; and " $\geq 11$ reports".

The characterization variables used were: gender (female; male); age group (from 20 to 39; from 40 to 61); professional category (nurse, nursing technician, nursing assistant); nurses' education level (complete superior; Graduate - specialization level); educational level of nursing technicians and assistants (complete high school, incomplete higher education, complete higher education); length of service in the hospital ( $\leq 5$ years; $>$
6 years); working time in the unit ( $\leq 5$ years; $>6$ years); other employment (yes; no), weekly workload at the institution $(<42$ hours; $\geq 42$ hours) and another employment relationship ( $\leq 20$ hours; $>20$ hours).

Prior to data collection, the tool was pre-tested with 12 nurses from the administrative staff of one of the assessed hospitals, to verify its adequacy regarding the font size and layout. No changes suggested by respondents.

After this step, the researcher contacted the coordinators of the units in each of the three hospitals to establish the dynamics of data collection, as well as request the number of employees, allowing the identification of those absent on the day or period between the delivery of the questionnaires. and its gathering. Up to four visits were made in each unit for each work shift. At the first meeting the professional was approached to explain the research objectives and invite him to participate. After acceptance, a sealed envelope with two copies of the informed consent form and the questionnaire was delivered, which could be answered at the time of delivery or at a more opportune time. For participants who did not answer the questionnaire at the time of delivery (day 1), up to three returns were made to collect the envelopes on days 2, 3 and 4 .

\section{Analysis of results, and statistics}

Data were double entered into a database using Microsoft Excel 2016 with inconsistency correction. Descriptive analyzes were performed using the Statistical Package for Social Sciences (SPSS), version 19.0.

For analysis of patient safety culture in general, the following formula was used: [(Sum of the results of the 12 dimensions/12) $x$ 100]. For analysis of each dimension of the safety culture the formula: [(Number of dimension positive responses/total number of valid responses to dimension items) $x$ 100].

From the calculation of the percentages, the following categories were assigned: areas considered strengthened ( $\geq 75.0 \%$ positive responses), areas with potential for improvement ( $<75.0 \%$ to $>50.0 \%)$, and areas $(\leq 50.0 \%)$, as proposed by the $\mathrm{AHQR}^{(26)}$.

To assess the reliability of the answers of the items and dimensions of the questionnaire, the internal consistency analysis was performed using Cronbach's alpha coefficient, the results vary from 0 to 1 , and the closer to number 1 , the greater the reliability; results below 0.7 indicate that the questionnaire does not measure the proposed factors $^{(28)}$.

\section{RESULTS}

Five hundred eighty-seven questionnaires were distributed to nursing workers. Of these, 101 questionnaires did not return and 19 were discarded because they had the same answer option in all questions, which corresponded to a response rate of $79.6 \%$ (82.6\% nurses and $77.4 \%$ nursing technicians and assistants).

The internal consistency of the tool, tested by Cronbach's alpha coefficient, was 0.84 .

Regarding sociodemographic and work characteristics, there was a predominance of female participants (88.4\%), between 20 and 39 years of age $(60.8 \%)$ and nursing technicians and assistants 
(57.2\%). Most nurses reported Graduate degree (76.0\%) and nursing technicians and assistants had completed high school (83.9\%).

Regarding length of work, there was a higher frequency of participants with five years or less in hospitals (57.8\%) and in units (82.0\%). All participants worked 42 hours per week and $20.8 \%$ had another work relationship.

Of the seven dimensions that make up the patient safety culture within the unit/sector organization (Table 1), four presented average percentages of positive responses, classified as culture with potential for improvement: "Teamwork within hospital units" (72.6\%), "Expectations and actions to promote the safety of supervisors and managers" (66.5\%), "Organizational learning" $(66.3 \%)$ and "Return of information and communication about errors" (58.8\%). The dimension "Teamwork within hospital units" differed between the responses of nurses and nursing technicians/ assistants, as only among nurses was classified as strengthened. The other dimensions presented average percentages of positive responses considered weak: "Openness to communication" (28.5\%), "Adequacy of professionals" (37.0\%), and "Non-punitive responses to errors" (21.9\%).

Table 1 - Frequency of positive responses of patient safety culture dimensions in high complexity institutions, according to professional category, Londrina, Paraná, Brazil, 2017

\begin{tabular}{lccc}
\hline & TEC/ & TET \\
DIMENSIONS & AUX TOTAL \\
& $\%$ & $\%$ & $\%$ \\
\hline
\end{tabular}

Patient safety culture within the unit/sector

organization

Teamwork within hospital units

$\begin{array}{lll}77.3 & 67.9 & 72.6\end{array}$

Supervisory/manager safety promotion

expectations and actions

Organizational learning

$65.9 \quad 67.1 \quad 66.5$

Return of information and communication about $\quad 63.2 \quad 54.4 \quad 58.8$

errors

Openness to communication

Professional suitability

Non-punitive responses to errors

$\begin{array}{lll}29.0 & 27.9 & 28.5\end{array}$

$\begin{array}{lll}40.7 & 33.3 & 37.0\end{array}$

$\begin{array}{lll}22.5 & 21.3 & 21.9\end{array}$

Patient safety culture within the hospital organization

Hospital management support for patient safety $\quad 45.1 \quad 51.8 \quad 48.5$

$\begin{array}{llll}\text { Teamwork within hospital units } & 39.5 & 42.9 & 41.2\end{array}$

$\begin{array}{llll}\text { Internal transfers and shift changes } & 43.6 & 43.6 & 43.6\end{array}$

Result dimensions

$\begin{array}{llll}\text { Generalized perceptions of patient safety } & 45.0 & 47.9 & 46.5\end{array}$

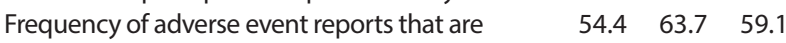
reported

Total

$49.4 \quad 49.0 \quad 49.2$

Note: Dimension classification according to percentage of positive responses: (strengthened: $\geq 75.0 \%$, improvement potential: $<75.0 \%$ to $>50.0 \%$, weakened: $\leq 50.0 \%$.

Regarding patient safety culture within the hospital organization (Table 1), the three dimensions presented average percentages of positive responses considered weak: "Hospital management support for patient safety" (48.5\%) "Teamwork within hospital units" (41.2\%), and "Internal transfers and shift changes" (43.6\%).

The answers of nursing technicians/assistants differed from nurses in the dimension "Hospital management support for patient safety", classified as weakened only by nurses (Table 1).
Of the two outcome dimensions (Table 1), the "Frequency of Reporting Adverse Events That Are Reported" presented a culture with potential for improvement (59.1\%). The dimension "Generalized perceptions about patient safety" presented a weak culture (46.5\%).

The average percentage of positive responses for the 12 dimensions of the patient safety culture was $49.2 \%$, being considered a fragile safety culture.

Regarding the patient safety culture (Patient safety degree) assessment (Figure 1), a higher frequency of assessments considered "Excellent/Very Good" was observed".

Regarding the number of adverse events reported in the last 12 months, only nurses have this function in the institutions surveyed; most responded "no reports" (58.5\%), followed by $37.5 \%$ who reported notifying " 1 to 10 reports".

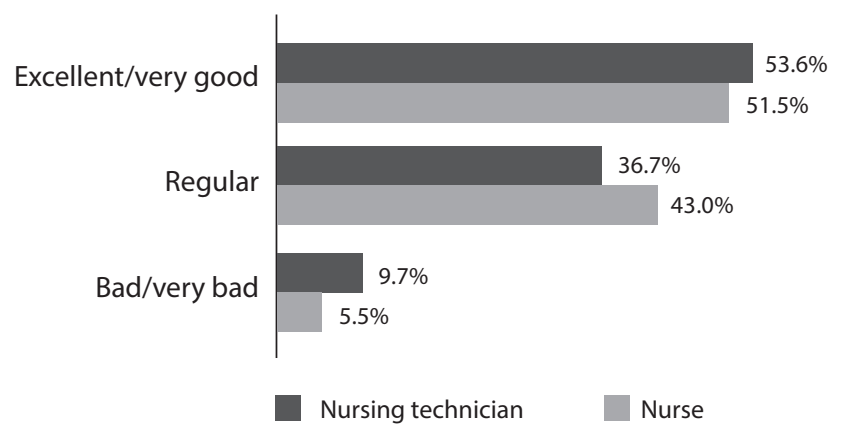

Figure 1 - Patient safety culture assessment in high complexity institutions, according to professional category, Londrina, Paraná, Brazil, 2017

\section{DISCUSSION}

The average percentage of positive responses to the dimensions of patient safety culture in the three hospital institutions was classified as weak (49.2\%). This result corroborates most studies found in $\operatorname{Brazi}^{(9-10,12,14-17,20,24)}$. Recognizing the strengths and weaknesses of the patient safety culture can be considered to provide opportunities for growth and increasingly positive outcomes for patients and healthcare institutions ${ }^{(20)}$. Later on, the dimensions considered weakened will be discussed.

The profile of nursing professionals who participated in this research is similar to that observed in the Brazilian reality, most often female ${ }^{(14,16-23)}$, aged between 20 and 39 years ${ }^{(17,19-20)}$, technicians or assistants ${ }^{(9-10,12,15-22,24)}$, working for up to five years in the institution $^{(9,12,14-17,20,24)}$ and workload of 42 hours per week ${ }^{(24)}$. Human resources factors interfere with safe care and the appreciation of nursing professionals is considered essential for patient safety ${ }^{(9,14,23)}$

The "Openness to communication" dimension considered weakened according to the respondents resembles other surveys conducted in Brazil ${ }^{(14,17,20)}$ and worldwide, according to a systematic review study ${ }^{(29)}$. Ineffective communication has been one of the main factors related to unsafe care and the occurrence of incidents in hospital institutions ${ }^{(30)}$. Thus, it is essential that workers have the perception of discussing freely when observing something that could affect the patient ${ }^{(11)}$.

To establish effective communication, it is necessary to involve management in everyday situations, aiming to reduce the 
hierarchy gradient ${ }^{(20,22)}$. As a form of improvement, the following stand out: adherence to human resources management improvement programs, involving the hierarchical levels; self-correction to avoid errors through incident assessment; the meetings between the teams; creating structured communication protocols and standardizing important patient information ${ }^{(30)}$.

The dimension "Adequacy of professionals", classified as weakened according to the respondents, was also assessed in other investigations on patient safety culture ${ }^{(16-17,20,24,29,31-35)}$. This result is probably due to the professionals' perception about the workload in the unit and the insufficient human resources for the effective performance of activities. Among the characteristics of the interviewed professionals that may have influenced this weakened assessment are the 42-hour weekly workload and the fact that $20 \%$ have a double bond. According to Amaral, Ribeiro and Paixão(36), nursing professionals work in conditions considered inappropriate due to the work environment and the activities performed. Factors such as psychological and physical exhaustion, lack of professional recognition, lack of materials, low pay, the need for double working hours, the incorrect dimensioning of professionals and night work reflect the dissatisfaction of the nursing worker ${ }^{(36)}$. These factors may reflect the quality of care provided to patients ${ }^{(37)}$ and the increase in adverse event and mortality rates ${ }^{(38)}$. The improvement of the working conditions of the nursing staff is considered fundamental to the strengthening of the patient safety culture ${ }^{(37-38)}$.

The dimension "Non-punitive responses to errors" was considered fragile, suggesting that professionals are apprehensive about experiencing or reporting an adverse event, possibly for fear of being blamed for the errors, through warnings, verbal punishments, dismissals and prosecutions, which leads to underreporting ${ }^{(32)}$. Event notification is considered an information tool that favors communication between professionals and senior management, as well as ensuring the improvement of institutional security ${ }^{(39)}$. The culture of guilt gives the professional responsibility for the error and prevents the identification of problems in the work processes, which contribute to its occurrence. A punitive culture discourages incident reporting and hinders organizational learning ${ }^{(40)}$. Healthcare organizations need a non-punitive culture that addresses errors in a systemic rather than individual manner and promotes learning from incidents ${ }^{(2)}$.

The low frequency of adverse event reporting by nurses suggests a punitive culture. It is noteworthy that the reporting of adverse events should not be restricted to nurses, although this category remains for 24 hours in the context of professional practice, cases of underreporting due to work overload may occur $^{(41)}$. In addition, all professional categories are authorized to report adverse events ${ }^{(41-42)}$ and reporting forms must be easily accessible, allowing for anonymous and voluntary filing ${ }^{(42)}$.

The dimension "Hospital management support for patient safety", classified as weakened by nurses, probably indicates the lack of management actions regarding the patient safety culture ${ }^{(11)}$. Nurses' autonomy is based on the support and involvement of their leaders, who in turn must know the difficulties that professionals face in daily life, in addition to establishing relationships of trust for the resolution of problems related to the work process, providing support for the planning of institutional changes ${ }^{(18)}$.
The development of the safety culture involves management, which must provide a working climate that prioritizes patient safety through investment of resources, development of effective communication and openness to discussion of errors to ensure continuous improvement ${ }^{(43)}$.

The fact that the dimension "Teamwork within hospital units" was classified as weakened may indicate that workers consider that inpatient units are not coordinated with each other to provide safe care $^{(11)}$, a result also evidenced in other studies ${ }^{(9-10,14,16-17,20,23-24,29)}$. The constitution of teamwork requires interaction between professionals, communication, empathy and support, and it is important to understand comprehensiveness and the exchange of knowledge in pursuit of the same goal. This is not done in isolation, it should be built through interaction between professionals, exposure of their feelings, skills, abilities and difficulties ${ }^{(44)}$. Developing a safety culture requires effective communication, coordination, cooperation and the development of educational interventions involving the multidisciplinary team, as teamwork is fundamental for quality assurance ${ }^{(45)}$.

The dimension "Internal transfers and shifts" was weak, a situation that has also been verified in other studies $(9,12,14,16-17,21,23-24,29,33,35)$. Shift change is an important moment, as it provides information on specific care and patient evolution, in order to maintain continuity of care and ensure patient safety. For the development of the security culture, the existence of standardization of information through protocols and checklist is fundamental, as well as other tools that assist in the transfer of information. In addition, the availability of professionals for the transmission of the necessary information and the recording of the relevant care items is important ${ }^{(46)}$. It is noteworthy that in the hospitals studied the shift change and the notification of adverse events are performed by means of a computerized tool, which depends on factors that help shift change, such as time, concentration and absence of noise.

Among the outcome dimensions, "Generalized perceptions of patient safety" was considered weakened by all professional categories, possibly explained by the vulnerability in the effectiveness of error prevention procedures and systems. It has been shown that there are weaknesses in the inpatient units, which can impair patient safety ${ }^{(11)}$, which corroborates with other studies $^{(9-10,12,14,16-17,20,23-24,29,35)}$.

Systems considered reliable are those that work with risk management mechanisms and reduce the occurrence of errors, because risks are expected in organizations. Thus, it is believed that the joint action with the other hierarchical levels in search of strategies aimed at the prevention or mitigation of risks, as a way to reduce the occurrence of adverse events, makes health organizations safer ${ }^{(47)}$.

Researchers ${ }^{(48)}$ suggest three changes for health care organizations to become highly reliable. The first is the involvement of "leadership" to prioritize patient safety at the organizational level. The second is the development of the "safety culture" so that errors are prevented before they pose major risks to the patient. Last but not least, "robust process improvement" is suggested through the use of quality tools that develop continuous improvement.

Even considering the result exposed about the fragile dimensions, most professionals of the institutions rated the patient 
safety as excellent or very good, a result observed in other studies $^{(9,16-17,20,24,35)}$. In countries where safety culture is best ranked, assessments are more judicious ${ }^{(9)}$. It is believed that the result observed in this research shows that the patient safety culture was not fully developed in the institutions under study and gives evidence of a culture of professional culpability.

To strengthen patient safety culture, it is necessary for management to act in a participatory manner and to realize that communication is the link between the needs of professionals, staff and patients. In addition, they need to ensure that teams are correctly sized so that their work is collaborative, coordinated, effective and safe. It is necessary to develop preventive actions that involve the whole health organization to aim for a culture of notification, non-punitive and organizational learning. Professionals need to be involved in patient safety issues for hospital management to change processes and routines ${ }^{(20-22)}$.

\section{Study limitations}

Among the weaknesses of this study, one of them was the restriction of the research to the nursing team, which made it impossible to identify the perception of other health professionals. However, the study has results that provoke reflections from a class that stays with the patient most of the time and represent the largest category of professionals in the hospital context.

It is still possible to consider as strength of this study the high return rate of the answered questionnaires compared to other similar studies ${ }^{(10,24)}$.

\section{Contributions to nursing and health}

The study represents health contributions in view of the patient safety culture, as it provides identification of fragile areas. It enables the planning, development and testing of educational strategies to ensure safe nursing care, and allows reflections on hypotheses that can be answered in future studies.

\section{CONCLUSIONS}

Patient safety culture - according to the perception of nursing professionals in the hospital institutions under study-was considered weakened. The most negative perceptions for the "Openness to communication"and "Non-punitive responses to errors" dimensions were highlighted. There was need for discussion on the subject and changes in strategies to improve the quality of care and promote safe care.

This brings us to the importance for the error not to be punished by managers, as it leads to the fear of notification by professionals. Thus, it is recommended to perform incident analysis using the quality tools to visualize the barriers that are being "damaged" during the process, enabling the proper handling of the incident in an educational and non-punitive manner. So, the safety culture will be built or modified safely.

It is suggested to carry out qualitative studies at national level on the culture of patient safety. It should seek to deepen the theme among the various health professionals, as well as research involving the development of educational interventions in order to strengthen patient safety culture.

\section{REFERENCES}

1. Ministério da Saúde (BR). Agência Nacional de Vigilância Sanitária (ANVISA). Relatório de Eventos Adversos período de março de 2014 a janeiro de 2018 [Internet]. 2018 [cited 2019 Jan 02]. Available from: https://www20.anvisa.gov.br/segurancadopaciente/index.php/ publicacoes/category/relatorios-dos-estados

2. World Health Organization (WHO). The conceptual framework for the international classification for patient safety v1.1: final technical report and technical annexes [Internet]. 2009 [cited 2016 Sep 20]. Available from: http://www.who.int/patientsafety/taxonomy/icps_full_ report.pdf

3. Ministério da Saúde (BR). Portaria no. 529, de 1 de abril de 2013. Institui o Programa Nacional de Segurança do Paciente (PNSP) [Internet]. 2013 [cited 2017 Mar 19]. Available from: http://bvsms.saude.gov.br/bvs/saudelegis/gm/2013/prt0529_01_04_2013.html

4. Ministério da Saúde (BR). Resolução RDC nº. 36, de 25 de julho de 2013. Institui ações para a segurança do paciente em serviços de saúde e dá outras providências [Internet]. 2013 [cited 2017 Mar 19]. Available from: http://bvsms.saude.gov.br/bvs/saudelegis/anvisa/2013/ rdc0036_25_07_2013.pdf

5. Nieva V, Sorra J. Safety culture assessment: a tool for improving patient safety in healthcare organizations. Qual Saf Health Care. 2003;12(Suppl 2):ii17-ii23. doi: 10.1136/qhc.12.suppl_2.ii17.

6. Fan CJ, Pawlik TM, Daniels T, Vernon N, Banks K, Westby P, et al. Association of safety culture with surgical site infection outcomes. J Am Coll Surg. 2016;222(2):122-8, doi: 10.1016/j.jamcollsurg.2015.11.008

7. Richter JP, Mcalearney AP. Targeted implementation of the Comprehensive Unit-Based Safety Program through an assessment of safety culture to minimize central line-associated bloodstream infections. Health Care Maneg Rev. 2018;43(1):42-49, 2018. doi: 10.1097/ HMR.0000000000000119

8. Berry JC, Davis JT, Bartman T, Hafer CC, Lieb LM, Khan N, et al. Improved safety culture and teamwork climate are associated with decreases in patient harm and hospital mortality across a hospital system. J Patient Saf, 2016. doi: 10.1097/PTS.0000000000000251

9. Macedo TR, Rocha PK, Tomazoni A, Souza S, Anders JC, Davis K. The culture of patient safety from the perspective of the pediatric emergency nursing team. Rev Esc Enferm USP. 2016;50(5):756-62. doi: 10.1590/S0080-623420160000600007

10. Tomazoni A, Rocha PK, Kusahara DM, Souza AIJ, Macedo TR. Evaluation of the patient safety culture in neonatal intensive care. Texto Contexto Enferm. 2015;24(1):161-9. doi: 10.1590/0104-07072015000490014 
11. Agency for healthcare research and quality (AHQR). Improving patient safety in hospitals: a resource list for users of the ahrq hospital survey on patient safety culture [Internet]. 2004 [cited 2017 Feb 20]. Available from: https://www.ahrq.gov/sops/quality-patient-safety/ patientsafetyculture/hospital/index.html

12. Mello JF, Barbosa SFFB. Patient safety culture in intensive care: nursing contributions. Rev Eletr Enf. 2013;19:a07. doi: 10.1590/ S0104-07072013000400031

13. Tomazoni A, Rocha PK, Ribeiro MB, Serapião LS, Souza S, Manzo. Perception of nursing and medical professionals on patient safety in neonatal intensive care units. Rev Gaúcha Enferm. 2017;38(1):e64996. doi: 10.1590/1983-1447.2017.01.64996

14. Minuzzi AP, Salum NC, Locks MOH. Assessment of patient safety culture in intensive care from the health team's perspective. Texto Contexto Enferm. 2016;25(2):e1610015. Doi: 10.1590/0104-07072016001610015

15. Tomazoni A, Rocha PK, Souza S, Anders JC, Malfussi HFC. Patient safety culture at neonatal intensive care units: perspectives of the nursing and medical team. Rev Latino-Am Enfermagem. 2014;22(5):755-63. doi: 10.1590/0104-1169.3624.2477

16. Cruz EDA, Rocha DJM, Mauricio AB, Ulbrich FS, Batista J, Maziero ECS. Safety culture among health professionals in a teaching hospital. Cogitare Enfermagem. 2018;23(1). doi: 10.5380/ce.v23i1.50717

17. Galvão TF, Lopes MCC, Oliva CCC, Araújo MEA, Silva MT. Patient safety culture in a university hospital. Rev Latino-Am Enfermagem. 2018;26:e3014. doi: 10.1590/1518-8345.2257.3014

18. Tavares APM, Mouta ECC, Avelino FVSD, Lopes VCA, Nogueira LT. Patient safety culture from the perspective of the nursing team. Rev Rene. 2018;19:e3152. doi: 10.15253/2175-6783.2018193152

19. Silva-Batalha EMSS, Melleiro MM. Patient safety culture in a teaching hospital: differences in perception existing in the different scenarios of this institution. HU Rev. 2016;42(2):133-42. doi: 10.1590/0104-07072015000192014

20. Costa DB, Ramos D, Gabriel CS, Bernardes A. Patient safety culture: evaluation by nursing professionals. Texto Contexto Enferm. 2018;27(3):e2670016. doi: 10.1590/0104-070720180002670016

21. Bião e Silva ACA de, Rosa DOS de. Cultura de segurança do paciente em organização hospitalar. Cogitare Enfermagem, v. 21, n. 5, 2016. doi: 10.5380/ce.v21i5.45583

22. Pinheiro MP da, Silva Junior OC da. Evaluación de la cultura de seguridad del paciente en una organización hospitalaria de um hospital universitario. Enferm Glob. 2017;16(1):309-52. doi: 10.6018/eglobal.16.1.238811

23. Fassarella CS, Camerini FG, Henrique DM de, Almeida LF de, Figueiredo MCB do. Evaluation of patient safety culture: comparative study in university hospitals. Rev Esc Enferm USP. 2018 52:e03379. doi: 10.1590/s1980-220×2017033803379

24. Andrade LEL, Lopes JM, Souza Filho MCM, Vieira-Jr RF, Farias LPC, Santos CCM, et al. Patient safety culture in three Brazilian hospitals with different types of management. Ciênc Saúde Coletiva. 2018;23(1):161-72. doi: 10.1590/1413-81232018231.24392015

25. Malta M, Cardoso LO, Bastos FI, Magnanini MMF, Silva CMFP. STROBE initiative: guidelines on reporting observational studies. Rev Saúde Pública 2010;44(3):559-65. doi: 10.1590/S0034-89102010000300021

26. Sorra J. Nieva VF. Hospital survey on patient safety culture. AHRQ Publication n. 04-0041. Rockville, MD: Agency for Healthcare Research and Quality [Internet] 2004[cited 2017 Feb 16]. Available from: http://www.ahrq.gov/qual/hospculture/hospcult.pdf

27. Ministério da Saúde (BR). Fundação Oswaldo Cruz (Fiocruz) [homepage na internet]. Pesquisa sobre segurança do paciente em hospitais (HSOPSC). 2013[cited 2017 Feb 16]. Available from: https://proqualis.net/sites/proqualis.net/files/000002442leoxaL.pdf

28. Cronbach LJ. Coefficient alpha and the internal structure of tests. Psychometrika. 1951;13(3). doi: 10.1007/BF02310555

29. Reis CT, Paiva SG, Sousa P. The patient safety culture: a systematic review by characteristics of hospital survey on patient safety culture dimensions. Int J Qual Health Care. 2018;30(9):660-77. doi: 10.1093/intqhc/mzy080

30. Nogueira JWS, Rodrigues MCS. Effective communication in teamwork in health: a challenge for patient safety. Cogitare Enferm. 2015;20(3). doi: $10.5380 /$ ce.v20i3.40016

31. Hefner JL, Hilligoss B, Knupp A, Bournique J, Sullivan J, Adkins E, Moffat-Bruce SD. Cultural transformation after implementation of a crew resource management: is it really possible? Am J Med Qual. 2017;32:384-90. doi: 10.1177/1062860616655424

32. Ammouri AA, Ak T, Mulira JK, Geethakrishnan R, Al-kindi SN. [Patient safety culture among nurses]. Int Nurs Rev. 2015;62(1):102-110. doi: 10.1111/inr.12159. Portuguese.

33. Okuyama JHH, Galvao TF, Silva MT. Healthcare professional's perception of patient safety measured by the hospital survey on patient safety culture: a systematic review and meta-analysis. Sci World J. 2018:9156301. doi: 10.1155/2018/9156301

34. Hayfaa A, Ibrahem SZ, Mudaf BA, Fadalah TA, Jamal D, El-jardari F. Baseline assessment of patient safety culture in public hospitals in Kuwait. BMC Health Serv Res. 2018;18(1):158. doi: 10.1186/s12913-018-2960-x

35. Nahed A, Cruz JP, Almoghairi AM,Al-otaibi RS, Almutairi KO, Alicante JG. Colet PC. Nurses' perceptions of patient: Safety Culture in Three Hospitals in Saudi Arabia. J Nurs Scholarsh. 2018;50(4):422-31. doi: 10.1111/jnu.1239

36. Amaral JF, Ribeiro JP, Paixão DX. Qualidade de vida no trabalho dos profissionais de enfermagem em ambiente hospitalar: uma revisão integrativa. Rev Espaço Saúde. 2015;16(1):66-74. doi: 10.22421/1517-7130.2015v16n1 p66

37. Cho E, Lee NJ, Kim EY, Kim S, Lee K, Park KO, et al. Nurse staffing level and overtime associated with patient safety, quality of care, and care 
left undone in hospitals: a cross-sectional study. Int J Nurs Stud. 2016;60:263-71. doi: 10.1016/j.jpurstu.2016.05.009

38. Fagerstrom L, Kinnunen M, Saarela J. Nursing workload, patient safety incidents and mortality: an observational study from Finland. BMJ Open, 2018;8(4):e016367. doi: 10.1136/bmjopen-2017-016367

39. Siman AG, Cunha SGS, Brito MJM. Nursing actions for patient safety in hospitals: integrative review. Rev Enferm. 2017;11(2):1016-1024. doi: 10.5205/reuol.10263-91568-1-RV.1102sup201718

40. Reis CT. Cultura de segurança do paciente. In: Sousa P, Mendes W(Org.). Segurança do paciente: criando organizações de saúde seguras. Rio de Janeiro: EAD/ENSP, 2014. p. 75-100.

41. Furini ACA, Nunes AA, Dallora MELV. Notificação de eventos adversos: caracterização dos eventos ocorridos em um complexo hospitalar. Rev Gaúcha Enferm. 2019;40(n-esp):e20180317. doi: 10.1590/1983-1447.2019.20180317

42. Ministério da Saúde (BR). Agência Nacional de Vigilância Sanitária (ANVISA). Sistema de notificações em vigilância sanitária (NOTIVISA) [Internet]. 2014 [cited 2017 Mar 19]. Available from: https://www20.anvisa.gov.br/segurancadopaciente/index.php/publicacoes/category/ manuais/2.

43. Moffat SB, Clark S, Dimaio M, Fann J. Leadership oversight for patient safety Programs: an essential element. Ann Thorac Surg. 2018;105(2):351-6. doi: 10.1016/j.athoracsur.2017.11.021

44. Duarte MLC, Boeck JN. Teamwork in nursing and the limits and possibilities of the family health strategy. Trab Educ Saúde. 2015;3(13):70920. doi: 10.1590/1981-7746-sip00054

45. Lee SH, Phillip HP, Todd D, Sallie JW, Peter JP. Handoffs, safety culture, and practices: evidence from the hospital survey on patient safety culture. BMC Health Serv Res. 2016;16(1):254. doi: 10.1186/s12913-016-1502-7

46. Barcellos GB. Comunicação entre os profissionais de saúde e a segurança do paciente. In: Sousa P, Mendes W. (Org). Segurança do paciente: criando organizações de saúde seguras. Rio de Janeiro: EAD/ENSP; 2014. p. 139-158.

47. Fragata J, Sousa P, Santos RS. Organizações de saúde seguras e fiáveis/confiáveis. In: Sousa P, Mendes W. (Org). Segurança do paciente: criando organizações de saúde seguras. Rio de Janeiro: EAD/ENSP, 2014. p. 17-36.

48. Chassin MR, Loeb JM. High-reliability health care: getting there from here. Milbank Q 2013;91(3):459. doi: 10.1111 / 1468-0009.12023 